\title{
MAQUINAÇÕES SATÂNICAS: EDWARD THOMPSON E AS LEITURAS DO SISTEMA FABRIL
}

\begin{abstract}
Adalberto Marson ${ }^{1}$
RESUMO: O artigo estuda a intertextualidade de escritos sobre fábricas na época da Revolução industrial, em particular do livro de Andrew Ure, através de Marx e do historiador Edward Thompson. Ure apresentava a idéia de um novo princípio reorganizador das relações humanas, que Marx desmascarou através da lógica dialética como um método de exploraçáo dos trabalhadores. Já Thompson, relacionou o racionalismo deista de Ure com a ideologia religiosa de disciplinarização do trabalho artesanal num sistema propriamente fabril. $O$ historiador resgatou tendências contraditórias da época, reconstituindo as mediaçóes entre o processo de dominação dos empresários industriais e as estratégias de resistência dos trabalhadores.
\end{abstract}

UNITERMOS: sistema fabril, revolução industrial, trabalho, religiăo, ideologia.

Entre os historiadores que contribuíram para a sensível alteração verificada nos métodos de reconstituição da história social está, indiscutivelmente, Edward P. Thompson ${ }^{2}$. Sua maneira sutil de repensar um elenco de conceitos e modelos interpretativos consolidados, para um tema aparentemente já esgotado, deixando que os próprios sujeitos históricos, no fluir da exposição documental, exerçam a prova de resistência do aparato conceitual, desmanchou inúmeras ortodoxias que habitavam as cabeças dos historiadores. Controvertidas proposiçôes thompsonianas - como, por exemplo, a imposição do capital por meios disciplinadores e morais, e não pela racionalidade da economia ou da técnica, e a capacidade de autonomia e resistência dos trabalhadores - geraram profundo

1 Departamento de História - IFCH/UNICAMP.

2 Refiro-me a The Making of the English Working Class. $7^{\circ}$ ed. Londres: Penguin Books, 1976. Citarei sempre as páginas desta edição, seguidas do correspondente na traduçáo brasileira (Sã̃o Paulo: Paz e Terra, 1987). 
impacto nas versōes consagradas, que consideravam "revolução industrial" uma realidade objetiva cujos "efeitos" explicavam a formação das classes.

Em que pese a ampla divulgação de sua obra no Brasil, muito pouco se conhece da acalorada polêmica que se seguiu a sua primeira publicação. Os interesses concentraram-se ou em medir até que ponto suas teses se afastavam do "marxismo ortodoxo", ou então, num fenômeno oposto, em conciliar sua diferente e especificamente histórica concepção de "disciplina" com a de Foucault e outros autores. Mal se percebeu que, por trás do impacto, subjaz um meticuloso trabalho de, a cada passo, remeter a certas matrizes de pensamento oriundas não apenas de Marx mas dos autores da economia política, da historiografia social inglesa do trabalho (labour history) e das correntes estruturalistas da sociologia. Fontes e parâmetros de discussão, tais heranças são duramente questionadas e confrontadas perante a documentação descoberta, porém jamais eliminadas como objetos gastos e sem valor.

Pela controvérsia em que se move e pelo diálogo insistente com tradições e ortodoxias, o método de Thompson tem ainda outra dimensão. Constitui um clássico exemplo de história conceitual. Atualmente em que o revival da narrativa ganhou preferências até do público consumidor de história, é oportuno mostrar a importância da discussão conceitual na reconstituição histórica, começando por reabilitar uma de suas exigências primeiras: o rigor da leitura ${ }^{3}$.

Discutirei, na verdade, três modalidades de leitura para uma determinada realidade, o sistema fabril na Inglaterra, a partir das obras de Andrew Ure ${ }^{4}$, Marx ${ }^{5}$ e Thompson. Nesse como em tantos outros casos, o confronto de leituras revelou que boa parte do que se toma geralmente por realidade histórica objetiva, reconstituída através de fontes fidedignas, se trata de uma construção deliberadora, com base em fragmentos e certos critérios escolhidos de interpretação. Além da inesperada importância da publicação de Ure, minha

3 Várias idélas do presente texto foram esclarecidas nos diálogos com meu colega de História contemporânea, Carlos Vesentini um cultor de leituras.

4 The Philosophy of Manufactures: or an exposition of the scientific, moral and commercial economy of the factory system of Great Britain. $2^{\circ}$ ed. (reimpressano). Londres: Frank Cass, 1967 (1" ed. 1835).

5 Utilizo a ediçశ̊o da Peaguin Books: Capital; a critique of Political Economy. $2^{\circ}$ ed. Londres: 1979, v. 1. 
surpresa foi também perceber que, muito antes da polêmica com Althusser, onde exlicita suas diferenças face aos aleijōes estruturalistas latentes no marxismo ${ }^{6}$, Thompson insinua algumas reservas a Marx, ora camufladas em alusões, ora jogadas para as letrinhas das notas de rodapé.

Vejamos, suscintamente, o que Ure representa em Marx. Quem examina o livro I d'O capital logo constata, que Ure tem participação decisiva na crítica aos princípios da economia política, o recorte por onde Marx desvenda os segredos da acumulação capitalista ${ }^{7}$. Angelo De Palma, que esquadrinhou com precisão a formação do pensamento econômico marxiano, salienta que foi da obra de Ure, que Marx retirou "a confirmação e a documentação das hipóteses mais gerais acerca das transformações internas do capitalismo e de sua superaçãon ${ }^{7}$. Dois aspectos são particularmente ressaltados por De Palma: o papel das forças produtivas da tecnologia, que atuam como força propulsora do desenvolvimento industrial $\mathrm{e}$ as conseqüências da mecanização, possibilitando, seja a completa subordinação do trabalhador ao processo de trabalho, seja a equiparação e a variação dos trabalhos a serem desempenhados nas máquinas.

A tese de De Palma pode, efetivamente, ser confirmada não só com relação a passagens d'O capital mas também em vários autores, que continuaram a formar idéias sobre a estrutura das forças produtivas com elementos conceituais o empíricos extraf́dos de Ure. É de perguntar se, embora sem citá-la, não seria devido à obsessão de Ure pela disciplina, que Marx foi levado a destacar o papel do código disciplinar na organização do trabalho fabril, em famosa comparaçăo

THOMPSON, E. P. A miséria da teoria ou um planetário de erros. Rio de Janeiro: Za har, 1981.

7 Conferir os capitulos do Livro I: A taxa de mais-valia; a jornada de trabalho; a divisăo do trabalho e a manufatura; maquinária e grande indústria.

8 Le macchine e l'industria da Smith a Marx. Turim: Einaudi, 1971, p. 70. Também a análise de Roberto Romano, embora ressalte o predomínio das fontes hegelianas e românticas da visåo que Marx tem da máquina, năo deixa de reconhecer'uma conjunçăo entre Ure e Marx nas "fantásticas discussōes ao redor dos autômatos", onde "a plétora de imagens organicas e mecânicas atinge o paroxismon". Corpo e cristal: Marx romantico. Rio de Janeiro: Guanabara Dois, 1985, p. 59. 
MARSON, Adalberto. Maquinaçṓes satânicas: Edward Thompson e as leituras do sistema fabril.

com o padrão militar de organização ${ }^{9}$.O mesmo pode ser constatado em Stephen Marglin. Em respaldo de sua tese acerca do poder disciplinar, rejeitando a explicação que prioriza a tecnologia, não é a outro senão a Ure, que Marglin recorre para documentar a estratégia de montagem das fábricas pelos primeiros capitalistas $^{10}$.

Em suma, estamos diante de uma persistência que tem atravessado as mais significativas discussões conceituais de fábrica. Por que a obra de Ure teria despertado tamanho interesse e exercido uma influência que Thompson chamaria de "satânica"?

A leitura de A filosofia das manufaturas não deixa ninguém impassível. Pontilhado de alusões mitológicas e entranhado na polêmica cultural e política, então desencadeada na Inglaterra a respeito das vantagens e necessidades da indústria, onde enfrenta polemistas tories da envergadura de um Southey, o livro empenha-se em grandioso propósito científico. Ure quer provar que o desempenho tecnicamente superior da máquina superava os instrumentos artesanais e rendia uma produção mais eficiente, de melhor qualidade e de custo mais reduzido, além de beneficiar o próprio operador, porque permitia a este

"É agora tẩo indispensável que um capitalista exerça o comando no campo da produção quanto um general comande no campo de batalha. (...) Um exército industrial de trabalhadores sob o comando de um capitalista exige, tal qual um exército comum, oficiais superiores (gerentes) e oficiais subalternos (contramestres, supervisores), que exerça o comando durante o processo de trabal ho em nome do capital". Capital, I, cap. 13 "Cooperação", p. 448-450. A convergência entre Ure e Marx na metáfora bélico-militar é apontada por Maxine Berg no livro The Machinery Question and the Making of Political Economy, 1815-1848.Cambridge, Cambridge Un. Press, 1982, p. 201. Diversos autores exploram a mesma analogia de Marx para explicar tanto as origens, quanto as formas despóticas dos métodos capitalistas de administração e controle do trabalho. Por exemplo: P. Mantoux - La revolución industrial en el siglo siglo XVIII. Madrid, Aguilar, 1962 (parte III, cap. II, p. 367-368); H. Braverman - Trabalho e capital monopolista. Rio de Janeiro, Zahar, 1977 (cap. 2, p. 65); S. Marglin - Origines et fonctions de la parcellisation des tâches - A quoi servent les patrons? In: A. Gorz (org.) - Critique de la division du travail. Paris, Seuil, 1973, p. 41-89; e, numa linha oposta, J. Querzola - Le chef d'orchestre à la main de fer: leninisme et taylorisme. In: L. Murard e P. Zylberman - Le soldat du travail. Paris, Recherches, 1978, pl 59.

10 Um longo trecho de Ure é citado por S. Marglin (ob. cit., p. 63-64). É justamente neste ponto que Dan Clawson centra of foco de sua crítica à tese do "controle social" de Marglin, porque corresponderia literalmente à visão que os capitalistas proeminentes e seus ideólogos tinham de si mesmos, na época em que estavam criando as primeiras fábricas e vencendo resistências e preconceitos. Dan Clawson. Bureaucracy and the Labor Process; the transformation of U.S. industry, 1880-1920. Nova Iorque: Monthly Review Press, 1980, p. 43-55. 
R. Histórla, Sño Paulo, n. 121, p. 45-66, ago/dez. 1989.

desempenhar uma atividade muito mais leve e confortável do que o labor "pesado" das especializações artesanais. Entre os detalhes merecedores de análise, cabe salientar que sua própria concepção de ciência é o ponto causador das maiores controvérsias e indignações. A "ciência da fábrica" ou "filosofia das manufaturas" carrega em si uma especial combinação de teoria e prática, sendo o providencial momento em que a ciência, recrutada a serviço do capital, dá origem à "fábrica automática". Esta significa um estágio superior que faculta à industria emancipar-se do trabalho qualificado (monopolizado pelos artesãos e seus conhecimentos), ao mesmo tempo que abre nova era para a humanidade. Além da pletora de riqueza e conforto, o mecanismo autônomo emanciparia o homem do fardo milenar do trabalho.

Entretanto, se a fábrica racionalizada solucionava, por uma questão técnica, as operações manuais do trabalho, Ure tèm consciência de que o operador teria que sofrer uma racionalização também de ordem científica, assentada na moral e na religião, a fim de que a natureza humana (tendencialmente fadada à corrupção) fosse transformada pela educação das crianças e pela readaptação dos adultos. As cenas em que Ure descreve crianças a executar operações nos teares mecanizados, qual se estivessem brincando e adultos que poderiam, nos intervalos do movimento automático, ler livros ou simplesmente descansar, soam como um insulto que ainda hoje nos choca. $O$ mesmo choque foi sentido na época, se lembrarmos as revoltas de trabalhadores contra as inovações mecânicas e as condições de trabalho na fábrica, bem como a polêmica instaurada sobre a questão do maquinismo.

Delírios de pastor evangélico, para uns, ou cínica apologia dos fabricantes, para outros, o fato é que a audácia da aberrante construção de Ure tem provocado resultados não menos aberrantes de ira e sedução. Em Marx, os embaraços podem ser notados, quando trata do conceito de fábrica e das conseqüências da mecanização.

Na abertura do item 4 ("A fábrica") do capítulo dedicado à "maquinaria e grande indústria", Marx dispõe certas afirmações de Ure de uma maneira tal a pensar-se que este, sem o mínimo de exatidão conceitual, trabalha com duas definições distintas de fábrica como se fossem equivalentes. Então, para que o abstrato chegue ao concreto e o conceito supere a coisa empírica, que Ure só apreende nas formas parciais da aparência, entra em cena o exercício superior da lógica dialética. Convenhamos: a superioridade intelectual de Marx em relação a Ure até pode ser admitida, mas o leitor d'O capital foi privado de uma verdade 
MARSON, Adalberto. Maquinaçōes satânicas: Edward Thompson e as leituras do sistema fabril.

elementar. Quem estabelece a distinçấo de um conceito comparado a vários outros, porque oferece um critério superior de abrangência e precisão, permitindo unificar matéria e idéia, é o próprio Ure, embora por um procedimento bastante contrário às lições hegelianas. Ure meramente parte do que é o mais "lato", em busca do mais "estrito senso". Com isso, apanha dois sentidos então correntes de fábrica, o "tecnológico" (que Marx nos diz ser um dos "lados" da definição) e o da "extensão", refutando a ambos por serem inadequados ${ }^{11}$. Este último, porque se presta a uma generalidade quase ilimitada, onde, por exemplo, se confundiria como fábrica desde uma cervejaria até uma oficina de carpintaria, e aquele, porque não contém algo essencial, a "série combinada" e o "motor primário" (prime mover). Logo, a denominação sistema de fábrica, "em seu sentido mais estrito, envolve a idéia de um vasto autômato, composto de vários órgãos intelectuais e mecânicos, agindo em acordo ininterrupto para produção de um objeto comum, e todos eles subordinados a uma força motriz auto-regulada" ${ }^{12}$.

Ou seja, a idéia de (suprimida por Marx) contém o pressuposto de um programa científico e disciplinador herdeiro de uma tradição racionalista do pensamento europeu. A fábrica não é mera realidade bruta. Elevada para a racionalidade do conceito, transforma-se num sujeito histórico que, por meio do automatismo, se propõe capaz de emancipar-se em direção a uma era de crescimento perene. É importante frisar que Ure discute o conceito depois de haver cristalizado a memória da indústria. Com a fábrica conceitualizada, pretende retomar o entendimento vigente na economia política e, ao mesmo tempo, superar o critério da "divisão do trabalho" numa crítica à autoridade de Adam Smith. A memorização do sistema de fábrica apresenta-se completa: cria-se o momento de origem, definem-se a obra e o criador (Arkwright) e institui-se o marco periodizador (uma data, inclusive). A preocupação de Ure em cindir o tempo e periodizá-lo estende-se por uma frequente reiteração da

11 "O termo Factory, em tecnologia, designa a operaçẫo de várias categorias de trabalhadores jovens e adultos, que cuidam com atenta habilidade de um sistema de máquinas produtoras continuamente impelidas por uma força central. (...) Alguns autores, de fato, têm compreendido sob o título factory todos os extensos estabelecimentos onde um número de pessoas cooperam entre si para um propósito criativo comum" (Ure, p. 13). 
R. Hlstória, São Paulo, n. 121, p. 45-66, ago/dez. 1989.

mitologia (os feitos dos antigos, agora superados), o que coloca a fábrica num patamar de civilização comparável ao momento de superaçāo do nomadismo ${ }^{13}$.

A idéia de fábrica é inseparável de uma outra que diz respeito às medidas regeneradoras a serem aplicadas aos homens industriosos, sem distinguir operários de patröes. Marx parece não sentir-se à vontade com a mistura de planos. Esforça-se em levantar incoerências e contradiçöes do texto. Exemplos: numa passagem, Ure explicaria a origem da organização vigente na fábrica, pelos motivos superiores de ordem técnica e científica; e noutra, por razões estritamente dependentes da vontade arbitrária dos seus dirigentes. Quando se encanta com o maquinismo central que fornece o movimento ("nessas salas espaçosas, a força benigna do vapor reúne à sua volta míriades de servidores dispostos"14, ele se trairia descrevendo um "autócrata" e não um simples "autômato". Finalmente, depois de ter admitido que, "em caso de alguma emergência", os dirigentes da fábrica podiam deslocar os trabalhadores de uma máquina a outra como lhes convinha, mais adiante comentaria que a facilidade de desiocamento entrava em direta contradiçăo com a "velha rotina" da divisăo do trabalho, ao que Marx objeta: em seu silêncio, Ure sequer se pergunta sobre o motivo de tal rotina ter sido abandonada.

Assim, o arranjo crítico de Marx consegue ofim desejado: ocultar do leitor que Ure tem aguda percepção do efeito disciplinador e do poder de domínio embutidos na máquina, uma acuidade alimentada pela convicção de que o conhecimento científico impusera sua supremacia porque vencera as técnicas

13 Por sua "empresa hercúlea", Arkwright mereceria ter seu nome lembrado entre os "espiritos-guias que persuadiram seus errantes companheiros a trocarem os precários trabalhos da caça pelo conforto sedentário da agricultura" (p. 17); a velha arte do tear, um dos benefícios de Minerva/Atenas à humanidade, teria atingido seu ápice na Inglaterra, "pois se uma donzela inglesa estiver agora sentada entre os habitantes ingênuos de alguma distante ilha da Austrália, com uma roda de fiar e um tear de iricô, seria sem dúvida saudada como uma visitante celestial" (p. 82); a invenção do tear automático, chamado pelos operários de Homem ferro, corresponderia a uma criaçáo do "nosso moderno Prometeu a pedido de Minerva", cujo "prodigio hercúleo" consistira em ter "estrangulado a Hidra da desordem" (p. 367). Essas e outras alusōes ao mito nấo têm função meramente decorativa; prestam-se a um proposito semelhante ao dissecado por Adorno e Horkheimer na trajetória do "esclarecimento". Recorre-se ao mito para recalcá-lo como um tempo superado, a um anterior remoto e "mitológico", enquanto a mesma função racionalizadora do mito é reapropriada pelo saber triunfante a serviço de uma apologia do progresso. A dialérica do esclarecimento. $2^{\circ}$ ed. Rio de Janeiro: Zahar, 1986 (cap. "O conceito de esclarecimento"). URE, A. Ob. cit., p. 18. 
MARSON, Adalberto. Maquinaçốes satânicas: Edward Thompson e as leituras do sistema fabril.

rotineiras de trabalho artesanal, que ainda subsistiam na organização da manufatura.

Na segunda questão, conseqüências da mecanização, encontramos o mais duro acerto de contas de Marx com o pretencioso "Dr. Ure". Depois de considerar que as inovações mecânicas haviam propiciado as armas mais poderosas do capital contra as revoltas operárias, critério pelo qual sugere uma reconstituição da história das invenções desde 1830, Marx prepara uma plausível montagem de frases de Ure em documentação do fato. Misturando afirmações de páginas diversas e sem obedecer à seqüência original, arremata com uma sentença fulminante: "Embora a obra de Ure tenha aparecido em 1835, numa época em que o sistema fabril ainda estava relativamente pouco desenvolvido, continua sendo a expressão clássica do espírito da fábrica, não só devido ao seu cinismo sem disfarce, mas também pela ingenuidade com que deixa escapar as contradiçōes irrefletidas do cérebro capitalista" ${ }^{15}$.

Dos quatro exemplos de contradições arroladas por Marx, tomo apenas o último, uma obra-prima de sutil operação de montagem. Marx se indigna com Ure porque este, embora seja um constante defensor das mais prolongadas jornadas de trabalho, se atreveria em certa passagem a conclamar aos trabalhadores que reconhecessem, agradecidos, à Providência, por esta lhes propiciar, com as máquinas, um "tempo livre para pensarem em seus interesses imortais".

Tal qual na questão anterior, Marx insiste em ridicularizar as preocupações moralizantes que se infiltram onde não devem: definição de conceitos e descrição de fatos. A frase acima citada consta de um parágrafo em que Ure está a demonstrar uma "grande doutrina": "quando o capital recruta a ciência a seu serviço, a mão refratária do trabalho sempre aprenderá a docilidade" ${ }^{16}$. O êxito da doutrina estaria já confirmado no ramo da impressão de fustões, onde fôra liquidado o domínio que os "oficiais" (journeymen) tradicionalmente exerciam sobre o ofício e os respecivos patrões. "À semelhança de mestres-de-obras

15 MARX, K.. Ob. cit., I, cap. 15 "maquinaria e grande indústria", item 5, p. 564.

16 URE, A.. p. 368. Contudo, é no cap. 14 ("A divisâo do trabalho e a manufatura", item 5) que Marx trabalha conceitualmente a idéia de ciência a serviço do capital, remetendo sua fonte nâo a Ure porém a W. Thompson. De tal modo consagrou-se a paternidade de Marx, que a tradição do marxismo perdeu o interesse pela origem da idéia. Ver, por exemplo, D. Montgomery. Workers' control in America. $2^{2}$ ed. Cambridge: Cambridge Un. Press, 1981 , p. 34. 
egípcios, os operários impressores ditavam ao industrial o número e a quantidade de aprendizes a serem admitidos no ofício, as horas de seu próprio trabalho e os salários a serem pagos. Até que finalmente os capitalistas procuraram livrar-se dessa intolerável servidão, recorrendo à ciência, e foram rapidamente reinstalados em seu domínio legítimo, isto é, o de cabeças acima dos membros inferiores" ${ }^{17}$.

Ure tem plena consciência de que o aparato automovido fôra projetado para combater "despóticas confederações" de trabalhadores qualificados; acusa-os de fomentarem greves por salários altos e por carga menor de trabalho e de se conservarem, com seus privilégios, "entrincheirados atrás das velhas linhas da divisão do trabalho". Graças à ciência, as "novas táticas mecânicas" estariam conseguindo derrubar as defesas operárias ancoradas na tradição, obrigando-as a uma rendição incondicional. O trabalhador qualificado, "homem de vista curta" e incapaz de perceber o alcance da inovação mecânica, preferia entregar-se ao desprezível comportamento de um atormentado. "Como seria bem diferente", lastima Ure, se ele calmamente incorporasse o "aperfeiçoamento designado pela Providência a fim de que ele libere suas funções animais do trabalho bruto e deixe seu princípio de inteligência livre para pensar em seus [its, isto é, do princípio e não do trabalhador ou da Providência] interesses imortais!"18. O mecanismo automático (não uma máquina qualquer), sendo fruto do serviço prestado pela ciência ao capital, cumpriria o desígnio divino porque ensinava a "docilidade" aos refratários à disciplina, os trabalhadores bloqueados por hábitos e privilégios. Equiparando-se ao industrial (cabeça e parte superior da organização do trabalho na fábrica), também a parte superior do homem trabalhador poderia usufruir com a máquina automática de uma liberdade para um aperfeiçoamento espiritual, antes impossível. Concordemos ou não com suas exaltações, Ure exibe a seu favor fatos publicados ou testemunhados. Em fábricas têxteis bem administradas, em que o motor a vapor comandava "batalhões de bobinas" com uma precisão "jamais igualada pelas tropas mais bem treinadas de Frederico, o Grande", os encarregados dos teares disporiam de tempo para ler livros inteiros e "podiam estudar os ciclos das ciências durante sua atividade ${ }^{19}$.

17 URE, A.. Ob. cit., p. 369.

18 lbidem, p. 370.

19 Ibidem, p. 370-71. 
Não é possível, pois, separar a descrição da fábrica (para documentar uma "realidade objetiva") dessa utopia, que vislumbra uma sociedade a ser constituída por homens (patrões e trabalhadores) moralizados pela religião do trabalho. Dir-se-ia que a obra da ciência, após recrutar os inventores, só está completa, quando o capital se póe a serviço da religiosidade. O fato de Marx retirar de Ure um esquema conceitual, descarnando-o das incoerências e da mistura de cinismo e ingenuidade própria de um "cérebro capitalista", indica que a ossatura daí resultante destina-se a preservar a fábrica no centro de racionalização da história. No cap. 32 do livro I ("Tendência histórica da acumulação capitalista"), entre os "desenvolvimentos" que, pela "ação das leis imanentes da própria produção capitalista", levariam à superação lógica do capitalismo, incluem-se duas características que são praticamente idênticas à formulação de Ure: "forma cooperativa do processo de trabalho [e] consciente aplicação técnica e da ciência". Pela dedução de Marx, a "expropriação dos expropriadores" obedeceria a uma lei evolutiva, a mesma "metamorfose" pela qual, em dado momento, o velho revestimento de um organismo se torna "incompatível com o novo conteúdo que nele se desenvolvera". Independente de qualquer averiguação histórica, ao menos no que tange ao desenvolvimento de uma teoria, não há dúvida que a metamorfose se cumpriu: o conceito burguês de fábrica, tal qual aparece na obra do Dr. Ure, foi efetivamente expropriado pela crítica dialética do Dr. Marx.

Já em Thompson, contemplamos um procedimento bem diverso, einbora o mesmo estatuto de documentação da realidade ainda permaneça. De um modo geral, Thompson segue uma tradição que pode ser remontada aos primórdios do saber erudito, de proceder com muita cautela antes de emitir qualquer juízo, quando há dois incompossíveis, de escolher mais de uma fonte na composição do tema e de evitar excessiva generalização, ou cunho de objetividade, quando a fonte é muito específica.

Apontemos um exemplo: a questão do trabalho infantil nas fábricas, que Thompson analisa no cap. 10 ("Padrões e experiências"), entremeada aos debates no Parlamento a propósito da redução da jornada de trabalho para 10 horas. Dois textos antagônicos dividiam as opiniōes. O primeiro, da comissão Sadler (1832), formada pelos tories, denunciava os males terríveis da fábrica e os abusos dos empregadores; o segundo, de uma comissão parlamentar de fábrica (1833), que expressava a visão otimista dos liberais, rebatera as acusações, juntando provas da boa conduta dos fabricantes e das saudáveis condições de trabalho. A 
R. Histórin, São Paulo, n. 121, p. 45-66, ago/dez. 1989.

publicação de A filosofia das manufaturas também pode ser vista como parte dessa campanha em defesa do sistema fabril. Frequentemente, Ure lança mão dos testemunhos recolhidos pela comissão parlamentar e por outras publicaçóes oficiais congêneres, a fim de corroborar o ponto de vista patronal, em fatos, números e argumentos.

Portanto, já na década de 1830 estava configurada a polarização da visão otimista versus a pessimista, que continuaria a reproduzir-se posteriormente na historiografia, que procurou avaliar os "efeitos sociais da revolução industrial" no mundo do trabalho. Thompson menciona o caso deveras característico dos autores da publicaçāo Capitalism and the historians, cujo esforço em sustentar que os testemunhos colhidos pelos inspetores da comissão liberal respondiam plenamente a quase todas as acusações externadas nos depoimentos operários da outra comissão, visava a precipuamente invalidar a tradição "pessimista" representada sobretudo pelos trabalhos dos Hammonds. Thompson intervém na polêmica admitindo a existência de limitações, parcialidades e alvos políticos na publicação da comissão Sadler, o que, entretanto, não lhe retira a credibilidade. Dada a contradição irreconciliável entre os testemunhos, pondera que a razão se perderia se desse preferência imediata, sem titubear, a uma única lógica, desqualificando a outra (no caso, a dos operários).

É com essa cautela, em si nada inovadora, que Thompson procura enfrentar o "caso" Ure; A filosofia das manufaturas tanto é citada inúmeras vezes (como simples fonte), quanto propicia discussōes temáticas carregadas de implicações ideológicas e políticas, nas quais, através de Ure, é Marx que desponta no horizonte da crítica.

Em dois momentos o encontro com Marx se dá explicitamente, ambos no cap. 11 ("O poder transformador da cruz"). Primeiro momento. Ao discutir o processo de substituição de trabalhadores adultos masculinos por mulheres e crianças, e artesãos experientes por operários comuns, Thompson chama a atenção, em nota, para a explicação dada por Ure, segundo o qual a transformação no processo de trabalho decorreria de um "objetivo e tendência constantes de cada aperfeiçoamento na maquinaria", a fim de "substituir por completo o trabalho humano ou diminuir seus custos" ${ }^{20}$. Comentário de Thompson: "Como expressão das intenções dos industriais, isso é algo interessante e até mesmo de 
relevância para o caso das indústrias têxteis; mas, como expressão de uma 'lei' do desenvolvimento capitalista, talvez Marx e Engels tenham dado crédito demais às afirmações de Ure ${ }^{n 21}$.

O que concluir dessa advertência? Uma primeira conclusão é mais ou menos óbvia: a impropriedade de deduzir-se uma lei para esse genérico desenvolvimento; tal dedução tanto se origina de um simples equívoco de Marx, por conferir credibilidade a uma fonte suspeita, quanto insinua a presença de uma mesma lógica em ambos, a que se identifica com a economia e a técnica. Outra conclusão possível: ao contrário de Marx, Thompson não se preocupa em denunciar incoerências de Ure, preferindo deixar evidenciado que, por trás do impessoal e abstrato "aperfeiçoamento na maquinaria" ou das construções em voz passiva, sempre existe um determinado sujeito social interessado naquele desenvolvimento. $O$ discurso científico de Ure é mantido dentro dos limites de sua temporalidade. Parcial (porque visão dos fabricantes) e restrito a um setor da indústria (têxtil), dele não há lei alguma a deduzir, senão a que compartilha da lógica nele pressuposta.

Segundo momento. Aqui, enveredamos pelos caminhos mais embaraçosos, que atravessam o tema central do capítulo 11, o relacionamento entre religião e capitalismo. De saída, percebe-se que, pelos títulos dados ao capítulo ("O poder transformador da Cruz") e ao primeiro item ("Maquinaria moral"), ambos extraídos literalmente, Thompson quer realmente debater com Ure, e nas áreas sombrias das maquinações mentais. $O$ tema, como se sabe, foi consagrado por grandes autores da sociologia (Weber e Tawney, por exemplo), que estabeleceram uma analogia explicativa entre o princípio de valor da economia mercantil e a visão utilitarista da ética protestante, particularmente a dos metodistas. Thompson considera que, não obstante essa explicação tipicamente econômica tenha dado conta dos motivos pelos quais muitos empresários aderiram aos hábitos metódicos e dedicaram especial interesse à disciplina, aqueles sociólogos nada disseram sobre a disseminação e o ajustamento do metodismo nos meios operários e populares. Seu problema, então, é saber como a disciplina metodista de trabalho conseguiu interiorizar-se nos trabalhadores, de modo a que esses se transformassem" em seus próprios feitores de escravos" (expressão de Weber). Eis o gancho: 
"É em Philosophy of Manufactures(1835) do Dr. Andrew Ure - um livro que, com sua advocacia satânica, muito influenciou Engels e Marx - que nós encontramos uma antecipação completa da alegação 'economicista' para a função da religião como uma disciplina de trabalho". 22

Vejamos as três ordens de implicações possíveis de serem desdobradas dessa avaliação sobre a obra de Ure: a primeira, como antecipação de uma teoria (a alegação ou hipótese economicista): a segunda, como elo de mediação entre o metodismo intelectual da elite burguesa e as práticas do metodismo popular; $\mathrm{e}$ a terceira, como influência "satânica" sobre Marx. As duas primeiras podem ser discutidas a partir de suas designações: termos comuns à linguagem forense (advocacy, case), coroados pelo "satânico", esse extremo de maldade que também é um efeito da malícia e da artimanha do advogado. A escolha não gratuita dos vocábulos está a indicar que, nos fundamentos da defesa de Ure, advogando a causa perversa da submissão de pessoas ao trabalho controlado pelos capitalistas, já está contida a base econômica que, passando por Marx, se converterá no principal argumento da hipótese tida por uma descoberta da mencionada explicação sociológica. Com efeito, basta o leitor conferir a distribuição dos assuntos para constatar que $A$ filosofia das manufaturas se inicia com duas longas partes dedicadas às bases econômicas e científicas do sistema fabril, completadas numa terceira voltada para a "economia moral", onde são tratadas as condições sociais, políticas e de saúde dos trabalhadores, bem como a religião e a cultura nas fábricas, parte essa em que Ure extravaza sua obsessão pela disciplina. Thompson, contudo, não adere à lógica dessa disposição, procurando remontar a construção científica de Ure "de trás para diante".

Exemplo perfeito é a definição de fábrica. A mesma frase ("idéia de vasto autômato etc"), premissa com a qual Marx abre a discussão conceitual de fábrica, continua sendo um ponto de partida em Thompson, mas para documentar o percurso de uma argumentação deliberadamente construída, cuja explicitude só se revela na "economia moral". A leitura de Thompson elege na definição de Ure um termo de ligação ("a subordinação do todo a uma força motriz auto-regulada"), por ser este o elemento que garante coesão interna ao maquinismo automático e permite a funcionalidade dos membros envolvidos na 
cooperação, tanto as operaçōes da máquina quanto os atos dos operadores. A característica principal da fábrica automática não residiria, portanto, em sua tecnologia, e sim no modo de administrá-la, para que fosse possível "distribuir os membros do aparato no corpo de cooperação" (Ure). O autômato complexo, dada a sua "regularidade invariável", exigia acima de tudo um treinamento especial dos "seres humanos", ou seja, a mudança dos hábitos de vida e de trabalho. De fato, logo após terminar a discussão científica de fábrica, Ure enfatiza que a grande façanha do sistema fabril consistira na elaboração de um "novo código", pelo qual foram solucionadas duas exigências do novo maquinismo: atenção e regularidade. Eis o porquê do pioneirismo de Arkwright: o ter concebido e administrado esse código.

Se continuarmos na leitura de Thompson, o conceito de fábrica de Ure só efetivamente se completa quando ultrapassa seu campo originário, o da economia e da técnica e se impregna das transformações morais aplicáveis na sociedade e na natureza humana. Ure constata que, embora o poder disciplinador da máquina em si, aliado à vigilancia dos contramestres, conseguia surtir efeito sobre crianças e pessoas inexperientes, fracassava entre os operários qualificados, por sua astúcia e indisposiçảo ao trabalho em recintos fechados, indisposição que ele atribui, inclusive, a uma alimentação inadequada. Chocado diante dos vícios, desregramentos e agitações políticas do ambiente social formado em torno das manufaturas, Ure exalta com entusiasmo a obra benevolente das "escolas dominicais". Propōe algo semelhante para o interior da fábrica, onde estaria grassando uma negligência de disciplina moral, responsável por "desordens do sistema geral, irregularidades das máquinas isoladas e desperdício de tempo e material" ${ }^{23}$. Os métodos convencionais de administração, baseados em salário, vigilância e puniçöes, the parecem ineficientes, daí conclamar o fabricante a "organizar sua maquinaria moral consoante os princípios de excelência de sua maquinaria mecânica, pois de outro modo ele jamais conseguirá comandar as mãos firmes, os olhos atentos e a cooperação imediata, essenciais à obtenção de um produto de excelência. Não há, de fato, nenhum outro caso em que a verdade do Evangelho - 'A piedade é o grande ganho' [Godliness is great gain] - seja mais aplicável do que na administração de uma grande fábrica" ${ }^{24}$.

23 URE, A.. Ob. cit., p. 417.

24 Ibidem, idem. 
R. IIlstórla, Sāo Paulo, n. 121, p. 45-66, ago/dez. 1989.

Com isso, arremata Thompson, Ure vinha completar o argumento já iniciado na preocupaçảo metodista com a disciplina. A natureza humana tinha que ser transformada de sorte a adaptar-se à disciplina da máquina. Uma vez que os trabalhadores estavam mal acostumados a encarar a piedade (como sentimento de religiosidade) apenas em troca de algum "ganho temporal", a única maneira de introjetar-lhes as "virtudes disciplinares" era inculcar neles a lição primeira do Evangelho: a "felicidade" verdadeira não está nesse mundo. Tal idéia permitiria resgatar o valor ético do trabalho, elevando-o a "um puro ato de virtude [grifos de Thompson], inspirado no amor de um Ser transcendente, que opera sobre nossa vontade e nossas afeições" ${ }^{25}$. O fecho do raciocínio é do próprio Ure, que Thompson apenas reproduz: "Onde, então, encontrará a humanidade este poder transformador? - na cruz de Cristo" ${ }^{26}$. Signo do sacrifício, a cruz fornece, para Ure, o motivo da obediência, o instrumento; que torna a obediência praticável, inevitável, constrangedora.

Contudo, nesse patamar em que Ure transcende os "vícios" da fábrica para galgar o púlpito, Thompson prefere deixá-lo nas alturas da transcendência, tratando de questōes mais mundanas da teologia, não sem uma acutilada irônica. Afinal, os industriais, podiam até concordar em serem considerados pessoas "eleitas" ou que seu sucesso fazia jus a uma graça, porém jamais se imbuíram de uma ascese de trabalho, a ponto de se tornarem monges. $\mathrm{O}$ ganho maior da campanha de "metodização", segundo Thompson, seria na verdade obtido por outros pregadores, como Wesley, cuja teologia, "em virtude de seu oportunismo promíscuo", melhor do que qualquer outra se prestava a servir de religião àqueles trabalhadores que não tinham a menor razão, em sua experiência social, de se sentirem "eleitos". Ao enquadrar a vida dos trabalhadores na metódica disciplina, a "religião do coração" concretizava a aspiração de Ure, redimindo o trabalho como um sinal de manifestação da graça, desde que desempenhado como "puro ato de virtude".

Constatamos, assim, porque o texto de Ure é essencial para Thompson amarrar o "ponto de junção" entre o utilitarismo de classe média e o metodismo popular. Quando Thompson incursiona pelas práticas đa "religião do coração" e expõe seus paradoxos e seu poder de penetração, chama nossa atenção a freqüência com que Ure é citado para documentar a existência de um conteúdo 
social (quando não econômico) na "estrutura do caráter", num movimento explicativo que funde a personalidade individual na classe social, a emoção íntima no drama coletivo.

Após demonstrar como à conversão do pecador produzia violenta alteração no caráter do trabalhador e do artesão pré-industrial, refundindo sua rebeldia em submissão, Thompson, conclui: "Aqui está, realmente, o 'poder transformador' de Ure". Ou seja, a operação de livrar o pecador do "poder de Satã" equivalia a um "fenômeno, quase diabólico em sua penetração nas próprias raízes da personalidade humana, direcionado para a repressão das energias emocionais e espirituais" 27 .

Em seguida, examinando a maneira pela qual uma vida cotidiana disciplinada se amoldava às exigências do trabalho fabril e como Deus onipresente no lar e na alma se convertia no "contramestre mais vigilante", sua interessante descrição termina entremeando a cruz do sacrifício à cruz do trabalho. "O metodista não aprendia somente a 'carregar sua cruz' de pobreza e humilhação; a crucificação era (como Ure o via) o próprio parâmetro de sua obediência: 'Verdadeiros seguidores de nosso Cordeiro sangrando, /Agora em Tua cruz diária nós morremos...' - o trabalho era a Cruz de onde o 'transformado" trabalhador industrial pendia" 28 .

Em síntese, Thompson quer mostrar que a "transformação" colocada por Ure teria finalmente encontrado uma efetiva realização social, embora por meio de uma prática religiosa não cogitada em sua obra. Esse me parece um lado questionável na instigante "junção" estabelecida por Thompson, especificamente quanto a duas hipóteses: o trabalho entendido como "puro ato de virtude" e a complementação de uma prática religiosa na outra.

Em relação à primeira, há uma objeção de ordem meramente tópica: não há essa concepção de trabalho em Ure. Se assim fosse, este teria admitido certa margem de eficácia na economia política aplicada e nos métodos convencionais de administração da fábrica, seja para melhorar o desempenho seja para mudar os hábitos dos trabalhadores. Para Ure, o trabalho em si não regenera, porém uma outra atitude perante o trabalho é capaz disso. Náo se trata de mero rodeio de palavras. Como qualquer ato útil,o trabalho para Ure significa virtude se, ao exercê-lo, o homem já houver recebido um preparo prévio desde criança. Dada 
a degeneração do ambiente social em que o trabalho está enredado, não é pelo seu desempenho que o homem, ser naturalmente "caído", poderia educar-se. Nas passagens em que reconhece o valor do trabalho, Ure reproduz o enfoque característico da economia política; isto é, a importância do valor-trabalho na constituição da riqueza nacional, associado à indústria e ao poder e a necessidade de uma ordem governando a "população fabril", tendencialmente sujeita a uma "grande convulsão".

Uma reconstituição do contexto discursivo permite-nos ver aí um objetivo diferente e mais pretencioso. A frase apanhada por Thompson prende-se a uma discussão de Ure sobre a importância de se educar os "pobres, mencionadas especificamente as "escolas dominicais" e as escolas junto a algumas fábricas. Ure volta sua crítica às "filosofias educacionais que desprezam o estudo da ciência da natureza humana, tal como é exposta no Evangelho" ${ }^{29}$, pedindo que seja inculcada nas crianças a lição fundamental do Evangelho (a felicidade não está neste mundo), "igualmente pela filosofia e pela religião". Na prática, exige que a ciência se subordine aos ditames da fé, o que significa uma reversão de suas declarações de teor científico nas primeiras partes do livro, por reivindicar à teologia o apanágio de "ciência", que melhor conviria ao mundo social e à natureza humana da era industrial. Denomina três posturas, que fracassaram na tentativa de solucionar os "tumultos", que agitam quase todas as classes da sociedade: a do economista, a do moralista e a dos teólogos racionalistas ou da igreja oficial. Suas "noções vagas" não conseguem dar origem ao "heroísmo da fé, ou à auto-imolação, para beneficiar o próximo"; por isso, Ure lança um apelo aos "puros atos de virtude", inspirados no amor de um Ser transcendente, não simplesmente como um sentimento de fé ("teísmo sentimental"), mas como uma "força moral" capaz de despertar o "poder transformador" identificado no exemplo da cruz, que se resume, por sua vez, numa especial, "obediência".

É importante seguir o percurso que leva a essa constatação. Antes, Ure havia elogiado as iniciativas de certos empresários, que patrocinavam escolas dentro ou perto das fábricas, onde as crianças "aprendiam a ser obedientes e ordeiras e a refrear suas paixões" ${ }^{30}$, virtudes que as tornavam bastante valorizadas e procuradas pelos empreiteiros de mão-de-obra infantil. Na mesma linha, logo após o elogio da obediência, havia exal tado a experiência da educação 
prussiana como sendo o melhor exemplo de aplicação do cristianismo na inculcação de hábitos adequados à indústria. No final do capítulo, sua maior satisfação é anunciar as mudanças havidas em certos distritos fabris, graças à "ampla circulação das Escrituras e ao aumento das escolas dominicais, os dois feitos mais gloriosos do nosso tempo", pois originavam uma "população moral" que faria as fábricas "florescerem com uma fertilidade crescente ${ }^{n^{31}}$.

Atente-se ainda que a formação dessa "população moral" dependia unilateralmente das atitudes dos empresários, cuja missão e exemplo deveriam pautar-se num conhecimento apropriado da "ciência mecânica", da economia política e da "maquinaria moral", ou, trocando em miúdos, deveriam adotar os princípios da fábrica automática, da política liberal e da linha evangélica. Os lamentos de Ure quanto à falta de disciplina moral e religiosa" e à disseminação de "preconceitos e vícios" referem-se preferencialmente à negligência dos fabricantes, cujos métodos de "coerção externa" reproduziam, num círculo vicioso, a visão distorcida de seus trabalhadores, que não se esforçam em ver "o capitalista frugal e empreendedor que os emprega como um benfeitor, mas com olhar hostil e invejoso" ${ }^{32}$. Com muita propriedade, Thompson destaca que a linha de racionalidade, que Ure julga existir na "maquinaria moral", nada mais é que a racionalidade do maquinismo empírico inventado para uma produção elevada e excelente. A cooperação, princípio unificador das tarefas divididas e das máquinas especializadas, só seria garantida por meio de um espírito de colaboração mútua que se nutre tanto na religiosidade como num refreamento dos instintos convertidos em autodisciplina e obediência participativa. Para Ure, os "delicados trabalhos da indústria automática" se exigem, de um lado, eliminaçăo dos hábitos "imprevidentes" e "dissolutos" dos trabalhadores, de outro impõem aos patrões outro modo de conduzir a fábrica e os trabalhadores, daf o apelo à godliness, a virtude da religiosidade como devoção e piedade. $O$ empresário deveria ser um virtuoso, que perceba a "delicadeza" do maquinismo, a fim de que seu exemplo gere comportamentos dóceis, ordeiros, atentos. A tríplice combinação religiosa-científica-mecânica garantiria a paz social e o 
funcionamento excelente do "vasto autômato", assegurando, consequentemente, a condição superior do empresário.

Nesse ponto, a leitura de Thompson acaba sendo prejudicada por reduzir a utopia de Ure a uma simples camuflagem para acobertar um projeto de inculcação da disciplina da máquina nos trabalhadores. Uma vez que prefere ironizar os efeitos da "teologia transcendental" de Ure entre os empresários, que se mostrariam indiferentes a qualquer apelo de uma ética monacal de trabalho, ficamos sem saber por que um divulgador prático como o dr. Ure insistia tanto na campanha religiosa se não dispunha de suporte político na classe para a qual estaria atuando como instrumento unilateral de dominação. Conforme salientei mais acima, há uma nítida intenção de Ure de transformar primeiro os empresários e seus métodos de gestão. Sem a automoralização prévia dos empresários, a disciplina religiosa que deseja ver incutida no trabalhador compreensivo (mais exatamente, na criança operária) não lograria sua transformação em operador presto e obediente, que considera uma exigência fundamental da racionalidade mecânica, no que, aliás, aplicava a matriz autoritária e elitista de todo o seu pensamento ${ }^{33}$.

Finalmente, quanto à segunda hípótese, Thompson mesmo nos diz que os resultados do metodismo popular de John Wesley e outros pregadores já se verificavam num momento histórico e num contexto social anteriores a, no mínimo, vinte anos da publicação de $A$ filosofia das manufaturas . Não ponho em dúvida os intercâmbios de uma religiosidade na outra, tampouco a presença dos conteúdos capitalistas nos símbolos religiosos, tão cuidadosamente desvendados por Thompson. Objeto, entretanto,que, sendo práticas que não se

33 Outros autores vêem a posiçấo de Ure em relação aos empresários de um prisma mais nuançado que o de Thompson. Para R. Bendix, mesmo as preocupações moralizadoras de Ure se enquadram nas "ideologias empresariais", que buscavam unificar os interesses dessa classe contra os conservadores e os artesãos, os dois flancos mais resistentes ao avanço do projeto liberal. Trabajo y autoridad en la industria. Buenos Aires: Eudeba, 1966, p. 94-98. Maxine Berg ( $O b$ cit., p. 179-202) reforça a mesma correspondência, avaliando as idéias de Ure dentro do debate travado nos Institutos de Mecânica e reproduzido em inúmeros escritos do perfodo 1820-1840, a respeito da "máquina" e do "sistema fabril". Entretanto, apesar de considerá-lo um autor "popular", que sugeria soluçốes eminentemente práticas, vê com muita estranheza o fato de a fábrica assumir na mente de Ure "qualidades claramente misticas". 
MARSON, Adalberto. Maquinaçőes satânicas: Edward Thompson e as leituras do sistema fabril.

reconhecem mutuamente, e por um elementar respeito à cronologia e à diversidade, talvez o texto de Ure não seja o mais adequado para a mediação,que parecerá fruto do arranjo do historiador.

Concluindo, resumirei os pontos que em Marx e em Thompson assinalam a importância de Ure para o conceito de fábrica:

1) como texto-documento, frequentemente equiparado aos relatórios dos inspetores de fábrica;

2) como expressão acabada de uma consciência de classe ou, na terminologia mais próxima de Marx, como um registro fiel da mentalidade empresarial;

3) como elaboração conceitual para diversos temas fundamentais da sociedade moldada na fábrica, destacando-se a análise precoce de alguns fenomenos, que Thompson equipara às explicações sociológicas de Weber;

4) como percepção ambígua e contraditória da realidade; aqui Marx ressalta, para contrapor-se a ela, os componentes de cinismo, deformação e incoerência, enquanto Thompson recolhe os sinais da constante presença de um sujeito (o empresário e seus interesses imediatos).

Por movimentos inversos, ambos intervêm no testemunho como sujeitos interpretantes, dispondo o sentido último das idéias de acordo com critérios de reconstituição organizados pelo historiador. Enquanto Marx preserva os indicadores de uma realidade objetiva, tema que possibilita conceituações e cuja transformação propicia, em seu devir, a base de negação do capitalismo, Thompson, inversamente, repõe a fábrica de Ure nos condicionamentos da visão limitada de um determinado sujeito social, não havendo aí uma realidade dotada de uma racionalidade imanente a partir de uma base (o sistema fabril), antes um complexo de visões e de interesses antagônicos. Em The making of the Working Class, a crítica à construção da história segundo os critérios específicos da fábrica só aparece de forma implícita,nas entrelinhas. Formulação clara e contundente será manifestada posteriormente, na polêmica com Althusser, 
quando, por exemplo, Thompson rebate o estruturalismo do historiador inglês Smelser ${ }^{34}$.

Não se trata, apenas, de inversão de pressupostos. O que Thompson recusa no tex to de Ure é o caráter de primazia como fonte, não o tomando como discurso único e homogêneo. Sua racionalidade, em princípio mantida, é confrontada pelo historiador à luz de outra racionalidade. $O$ sistema fabril até podia engendrar suas "leis", ajustadas a seu mecanismo; porém, o que o movimentava eram as idéias e ações deliberadas, ainda que contraditórias, dos sujeitos que tinham o poder de fazê-lo existir e funcionar como uma economia.

Entendemos, assim, porque o mesmo fenômeno de maquinação satânica, que adornou a exigência de uma disciplina de trabalho com as roupagens do aperfeiçoamento moral, também enredou Marx nas astúcias do conceito. É sintomático, que Thompson tenha se interessado mais pelo lado sombrio, perverso e hipócrito da "economia moral" de Ure, certamente porque aí está o vínculo, que assegura organicidade aos conceitos aplicados na economia e nas demais técnicas. É provável que o discurso da fábrica de Ure conseguiu impor sua força a Marx por ter, na época, consistência e originalidade. Como Marx não está particularmente interessado em recuperar fragmentos de outras percepções fora da economia política, sua crítica ao sistema fabril sucumbe à memória pronta que recebe de Ure. $\mathrm{O}$ que mais diferencia Thompson, neste aspecto, é a busca de outra leitura que, enfrentando a primazia da fábrica, procura recuperar os fragmentos das experiências dos trabalhadores, nos quais a fábrica ainda não se apresentava como realidade objetiva,pelo menos enquanto esses trabalhadores ainda não tinham sido inteiramente derrotados.

Não se justificam, portanto, leituras esquemáticas de Thompson, que elegem a parte "operária" da luta como sendo a razão da história, separada dos demais sujeitos. Dominação, disciplina e conhecimento científico, armas da classe capitalista contra resistência,autonomia e saber da experiência, armas da classe operária, constituem em Thompson pontos extremos e contraditórios da luta de hegemonia da fábrica. Na memória da fábrica, que se incrusta no discurso de Ure estão conscientemente presentes os termos polarizadores da luta; ela,e não o historiador, é quem os cria no processo de confecção de um saber. Pelas

"O 'sistema social' nâo tinha 'meta', nenhuma intencionalidade interiorizada, já que os homens e mulheres em seu interior tinham metas e intenções opostas". A miséria da teoria, p. 91. 
MARSON, Adalberto. Maquinaçōes satânicas: Edward Thompson e as leituras do sistema fabril.

tradiçōes e fragmentos dos testemunhos operários, Thompson reconstitui com precisão (de resto, com auxílio de todo um saber anterior) açōes conscientes que enfrentam mas não existem sem as potências da memória oposta, tampouco sem o saber que a acompanha.

ABSTRACT: The author elaborates through the writings of Andrew Ure different interpretations of labor changes as interpreted by Marx and by the historian Edward P. Thompson. From the scientificist argument of the invention of a technological mechanism for re-organizing human relation, Marx detected the dialectical process of exploitation of the working class. Thompson, on the other hand, discerns different mediations in this process, mainly the role of religious faith in the disciplinarization of industrial labor. The historian is mainly interested in reconstituting antagonistic values that opposed entrepreuneurial hegemony and the making of the working classes.

UNITERMS: industrial revolution, political economy, work discipline, religious ideology. 